\title{
Life Histories and Action Research
}

\author{
by Penny Van Esterik
}

Responding to Doreen Indra's comments on the research paradigm, one strategy for keeping gender issues central to refugee issues is the collection of life histories of refugee women of different ages and backgrounds. These biographies document life changes and significant events in these women's lives in their birthplaces, in the camps, and in the country of asylum. Viewing the refugee process from the perspective of individual women's lives provides another approach to complement more quantitative research. After collecting a number of representative biographies, analysts could look for common themes and issues emerging from the life histories. In this way we could interpret events through their impact on local communities and specific individuals.

There might be several practical applications for research of this kind. The process of constructing one's life history might have real psychological benefits as women come to view their personal worth and identity through the eyes of a sympathetic listener. In addition, we might begin to identify the factors promoting and hindering successful adjustment in North American communities. For example, we know refugee women who sit isolated, depressed, and powerless in their communities, and refugee women who hold together their families and friends while pursuing activity schedules that would exhaust many of us. Life histories would help us understand the differences between these groups of women. In addition, life histories are an excellent source of action research questions -- research which can inform new programme initiatives for refugee women. For example:

1. How do refugee women utilize their time? How do they find time to participate in whatever language, skills, income generating or cultural adaptation programmes that would assist them?
2. What work conditions do refugee women face?

3. How is the content of English as a Second Language (ESL) courses relevant to the life experience and needs of refugee women?

4. How do refugee women deal with the educational system on behalf of their children? What are their expectations regarding the education of their male and female children?

5. What informal systems have refugee women developed to deal with child care, medical problems, housing, and food shortages?

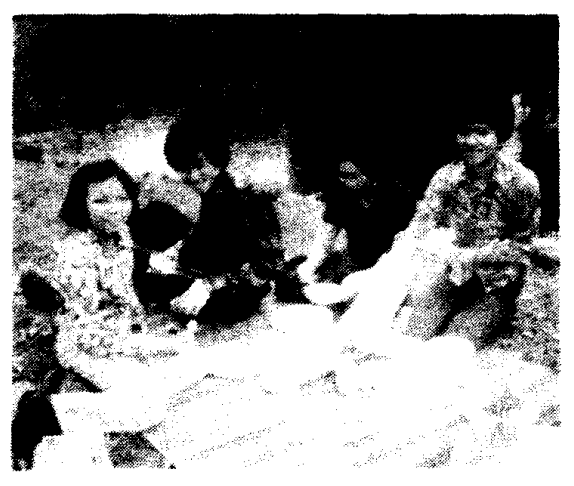

For a Cambodian refugee family, life in Canada now means freedom to play.

6. How do refugee female heads of household differ from male heads of household in adjusting to resettlement?

7. Are refugee women more at nutritional risk than refugee men?

8. What are the most important markers of personal and ethnic identity for refugee women?
One Cambodian Woman: For example, the life story of one Cambodian woman reflects more generally on the experiences of Southeast Asian women. Her life story (to be published in a forthcoming issue of the Atkinson Review dedicated to Refugees) reveals both structural features and personal characteristics that may be important predictors of successful refugec adjustment.

Throughout her life in Cambodia, this woman's commercial and entrepreneurial skills were encouraged and utilized. Consequently, she developed a calculating sense of how to use profits to insure her family's security. In spite of (or perhaps as a result of) her concern with the careful shepherding of economic resources, she spent a proportion of her profits on the regular support of the religious institutions of Theravada Buddhism. During the years under the Pol Pot regime and the family's escape, she struggled to reunite the extended family and keep it intact after the decision to flee. Her commitment to family is demonstrated by her decision to include two elderly sick female relatives in her family's escape and resettlement plans, even though they represented a financial burden on the family's scant resources.

There are certain structural characteristics of her situation which contributed to her capacity to adjust to the new sets of constraints and opportunities facing her as a refugee. First, her children were teenagers and took responsibility for themselves. In addition, the youngest son and daughter (thirteen years and fourteenyears-old, respectively) took over the domestic work of running the household, leaving their mother free to attend English classes and vocational training. Second, as a widow she was entitled to certain benefits and treated as a female head of household, eligible for ESL classes, basic education, and vocational training. In 